\title{
Necessity for detection of SARS-CoV-2 RNA in multiple types of specimens for the discharge of the patients with COVID-19
}

Yongqing Tong ${ }^{1 \dagger}$, Anyu Bao ${ }^{1 \dagger}$, Hongbing Chen ${ }^{2 \dagger}$, Jingtao Huang ${ }^{1}$, Zhihua Lv ${ }^{1}$, Lina Feng ${ }^{1}$, Yun Cheng ${ }^{2}$, Youna Wang ${ }^{2}$, Li Bai ${ }^{1}$, Wenlong Rao ${ }^{1}$, Hongyun Zheng ${ }^{1}$, Zegang Wu ${ }^{1}$, Bin Qiao ${ }^{1}$, Zhijun Zhao ${ }^{3 *}$, Huiming Wang ${ }^{4^{*}}$ and Yan $\mathrm{Li}^{1^{*}}$ (D)

\begin{abstract}
Background: The SARS-CoV-2 RNA was detected positive again after discharged from hospital in some COVID-19 patients, with or without clinical symptoms such as fever or dry cough.

Methods: 1008 severe COVID-19 patients, with SARS-CoV-2 RNA positive detected with the mixed specimen of nasopharyngeal swab and oropharyngeal swab by real-time fluorescence quantitative PCR (RT-qPCR), were selected to monitor SARS-CoV-2 RNA with the 12 types of specimens by RT-qPCR during hospitalization. All of 20 discharged cases with COVID-19 were selected to detect SARS-CoV-2 RNA in isolation period with 7 types of specimens by RTqPCR before releasing the isolation period.

Results: Of the enrolled 1008 severe patients, the nasopharyngeal swab specimens showed the highest positive rate of SARS-CoV-2 RNA (71.06\%), followed by alveolar lavage fluid (66.67\%), oropharyngeal swab (30.77\%), sputum (28.53\%), urine (16.30\%), blood (12.5\%), stool (12.21\%), anal swab (11.22\%) and corneal secretion (2.99\%), and SARSCoV-2 RNA couldn't be detected in other types of specimen in this study. Of the 20 discharged cases during the isolation period, the positive rate of SARS-CoV-2 RNA was 30\% (6/20): 2 cases were positive in sputum at the eighth and ninth day after discharge, respectively, 1 case was positive in nasopharynx swab at the sixth day after discharge, 1 case was positive in anal swab at the eighth day after discharge, and 1 case was positive in 3 specimens (nasopharynx swab, oropharynx swab and sputum) simultaneously at the fourth day after discharge, and no positive SARS-CoV-2 RNA was detected in other specimens including stool, urine and blood at the discharged patients.
\end{abstract}

\footnotetext{
*Correspondence: zhaozhijun@nxmu.edu.cn; rm000301@whu.edu.cn; yanlicmdc@163.com

†Yongqing Tong, Anyu Bao and Hongbing Chen contributed equally to this work

1 Department of Clinical Laboratory, Renmin Hospital of Wuhan University, Wuhan 430060, China

${ }^{3}$ Clinical Laboratory Center \& Ningxia Key Laboratory of Clinical and Pathogenic Microbiology, General Hospital of Ningxia Medical University, Yinchuan 750004, China

${ }^{4}$ Department of Nephrology, Renmin Hospital of Wuhan University, Wuhan 430060, China

Full list of author information is available at the end of the article
}

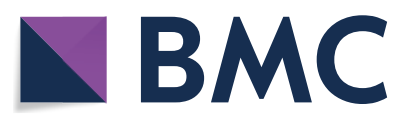

(C) The Author(s) 2020. This article is licensed under a Creative Commons Attribution 4.0 International License, which permits use, sharing, adaptation, distribution and reproduction in any medium or format, as long as you give appropriate credit to the original author(s) and the source, provide a link to the Creative Commons licence, and indicate if changes were made. The images or other third party material in this article are included in the article's Creative Commons licence, unless indicated otherwise in a credit line to the material. If material is not included in the article's Creative Commons licence and your intended use is not permitted by statutory regulation or exceeds the permitted use, you will need to obtain permission directly from the copyright holder. To view a copy of this licence, visit http://creativeco mmons.org/licenses/by/4.0/. The Creative Commons Public Domain Dedication waiver (http://creativecommons.org/publicdomain/ zero/1.0/) applies to the data made available in this article, unless otherwise stated in a credit line to the data. 
Conclusions: SARS-CoV-2 RNA should be detected in multiple specimens, such as nasopharynx swab, oropharynx swab, sputum, and if necessary, stool and anal swab specimens should be performed simultaneously at discharge when the patients were considered for clinical cure and before releasing the isolation period.

Keywords: COVID-19, SARS-CoV-2, RT-qPCR, Multiple specimens, Discharge criteria

\section{Introduction}

The coronavirus disease 2019 (COVID-19) has become a pandemic over the past months, with $4,962,707$ confirmed cases and 326,459 deaths reported in more than 215 countries, areas, or territories by May 22, 2020 (Data from COVID-19 Dashboard website, Johns Hopkins University) [1-3]. Furthermore, there is no specific medicine or vaccine for treating with COVID-19 [4, 5], so the key measure for fighting against the epidemic is to control and reduce the source of infection.

Severe Acute Respiratory Syndrome Coronavirus 2 (SARS-CoV-2) [6], the pathogenic cause of COVID-19, has been detected in multiple types of specimen, such as nasopharyngeal swab, oropharyngeal swab, sputum, stool, anal swab, and peripheral blood, et al. [7, 8]. The patients with COVID-19 will be discharged from hospital when their symptoms meet with criteria of clinical cure, and the SARS-CoV-2 RNA is negative in two consecutive respiratory specimens by real-time fluorescence quantitative PCR (RT-qPCR) (at least 1 day of sampling time interval) [9]. However, it had been reported that the detected viral RNA results turned back to "positive" in some patients recovered from COVID-19 [10, 11]. Whether these patients were discharged with false negative results or infected again remains unclear. It is urgent to improve the criteria of viral RNA detecting for monitoring the progress of disease and discharged patients.

The aim of this study is to describe the recovery positive, which indicates that the SARS-CoV-2 RNA is not completely cleared, for the discharge of the patients with COVID-19. Firstly, we analyzed the possible sites of infection in hospitalized patients with COVID-19 by detecting viral RNA with 12 different types of specimens, including nasopharyngeal swab, oropharyngeal swab, sputum, bronchoalveolar lavage fluid (BALF), stool, anal swab, urine, peritoneal dialysis fluid (PDF), blood, sweat, cerebrospinal fluid (CSF) and corneal secretion. Furthermore, we performed the same detection with 7 different specimens, including nasopharyngeal swab, oropharynx swab, sputum, blood, stool, anal swab and urine, for clinically cured COVID-19 patients to evaluate if it is appropriate to set criteria of discharge with continuously negative results of viral RNA detection in nasopharynx swab.

\section{Materials and methods Patients}

A total of 1008 severe COVID-19 patients with positive SARS-CoV-2 RNA by RT-qPCR method with mixed specimens of nasopharyngeal swab and oropharyngeal swab, were enrolled from February 1 to February 28, 2020 hospitalized in the east branch of Renmin Hospital of Wuhan University. The diagnosis criteria of COVID-19 was in accordance with Diagnosis and treatment guidelines of coronavirus disease 2019 in China-7th Edition [12]. Severe patients should meet any of the following criteria: (1) Respiratory distress ( $\geqq 30$ breaths/min); (2) Oxygen saturation $\leq 93 \%$ at rest; (3) Arterial partial pressure of oxygen $\left(\mathrm{PaO}_{2}\right) /$ fraction of inspired oxygen $\left(\mathrm{FiO}_{2}\right) \leqq$ $300 \mathrm{mmHg}(1 \mathrm{mmHg}=0.133 \mathrm{kPa})$. In high-altitude areas (at an altitude of over 1000 meters above the sea level), $\mathrm{PaO}_{2} / \mathrm{FiO}_{2}$ shall be corrected by the following formula: $\mathrm{PaO}_{2} / \mathrm{FiO}_{2} \times$ [Atmospheric pressure $(\mathrm{mmHg}) / 760$ ]. Cases with chest imaging that showed obvious lesion progression within 24-48 $h>50 \%$; (4) Respiratory failure and requiring mechanical ventilation; (5) Shock; (6) With other organ failure that requires ICU care. According to the patients' diagnosis and symptoms, SARS-CoV-2 RNA was detected in the collected the specimens available from the upper respiratory tract (nasopharynx and oropharynx) and lower respiratory tract (sputum and alveolar lavage fluid), digestive system (intestinal tract and anus), urinary system (urine), blood system (peripheral blood), conjunctiva (conjunctival secretion), the nervous system (cerebrospinal fluid, CSF), peritoneal dialysis fluid (PDF), corneal secretion and sweat glands (sweat) for each hospitalized patients with COVID-19 (Fig. 1). All of the specimens were collected from the first day to end day during the hospitalization in the severe patients. This study was approved by the ethics committees of the Renmin Hospital of Wuhan University (WDRY2020-K078) and was exempted from the need for informed consent.

The 20 discharged cases of COVID-19, the criteria [12] for which was the SARS-CoV-2 virus RNA detection negative in two consecutive respiratory specimens (at least 1 day of time interval of sampling) for patients who have reached the standards of isolation period (14 days) after clinical cured, during the isolation period were selected to detect SARS-CoV-2 RNA with multiple specimens including nasopharyngeal swab, oropharyngeal swab, sputum, stool, anal swab, urine and blood. This study was 


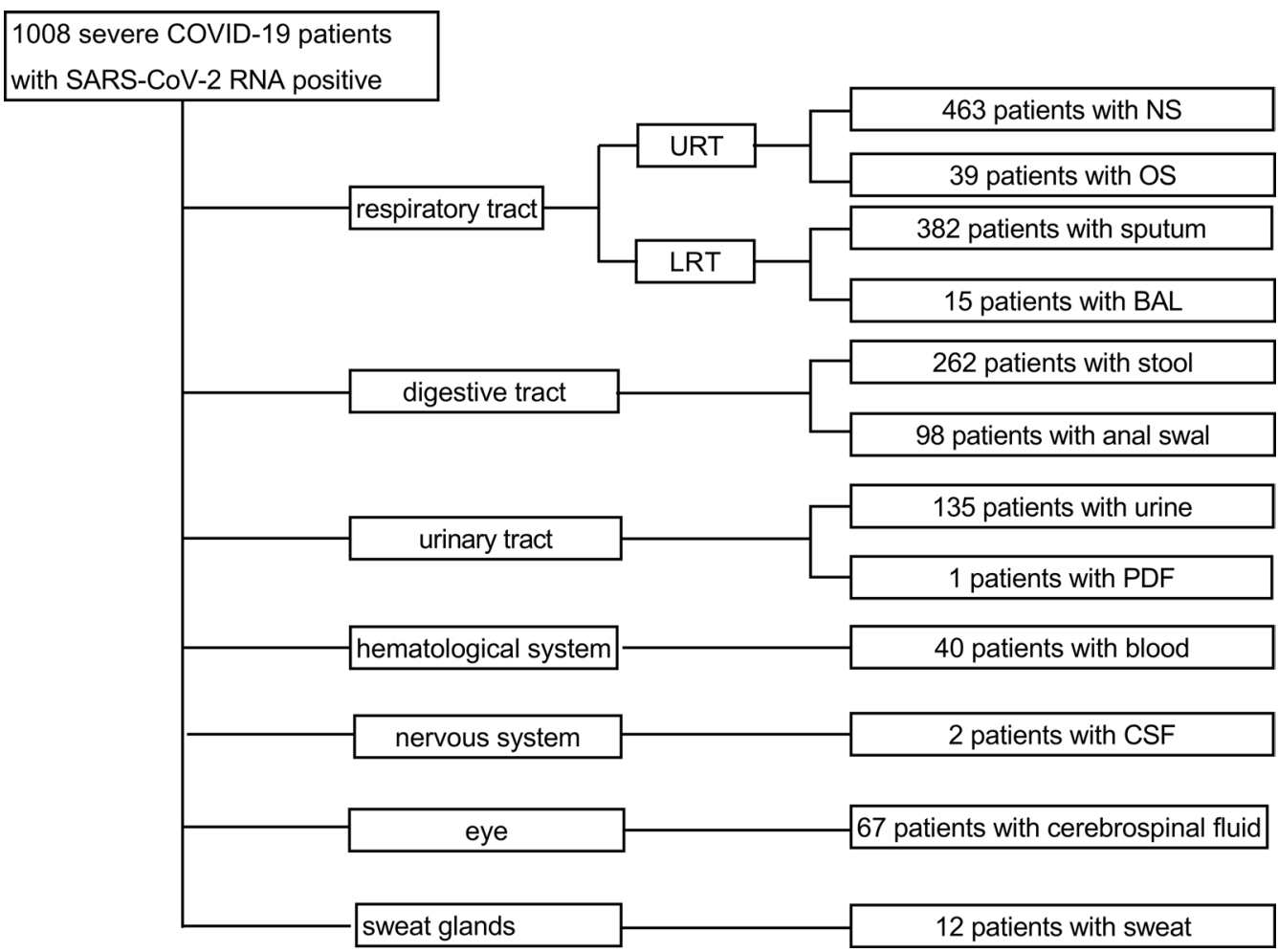

Fig. 1 Distribution of different types of specimens in COVID-19 patients. The 12 types of specimens collected from 8 types of tissues to monitor SARS-CoV-2 from the 1008 confirmed severe patient during hospitalization. The 12 types of specimens included nasopharyngeal swab, oropharyngeal swab, sputum, BALF, stool, anal swab, urine, PDF, blood, sweat, CSF, and corneal secretion. 8 types of tissues included respiratory tract, gastrointestinal tract, urinary system, blood, eyes, the nervous system and sweat gland. NS, nasopharyngeal swab; OS, oropharyngeal swab; BALF, bronchoalveolar lavage fluid; PDF, peritoneal dialysis fluid; CSF, cerebrospinal fluid

approved by the ethics committees of the Renmin Hospital of Wuhan University (WDRY2020-K078) and written inform consent was obtained from the patients.

\section{Specimen collection and pre-processing}

All collected specimens were pre-processed before RNA extraction. The PBMCs (peripheral blood mononuclear cells) were isolated from peripheral blood specimens with lymphocyte separation buffer. The urinary specimens were centrifuged at $3500 \mathrm{rpm}$ for $20 \mathrm{~min}$ to get the sediment. Sputum was liquefied with $4 \% \mathrm{NaOH}$ for $5 \mathrm{~min}$. The bean-sized stool specimens were mixed with saline solution for blending. All swab specimens were mixed with cell storage buffer and vortexed for 5 to $10 \mathrm{~s}$.

\section{RT-qPCR to detect the SARS-CoV-2 RNA}

RNA in the specimens were extracted using Magnetic Beads RNA Extraction Kit (Health Gene Technologies, Ningbo, China) and SuperPure automatic nucleic acid extraction instrument (Fosun Pharma, Shanghai, China) according to manufacturer's protocol. SARS-CoV-2 RTqPCR Kit (Shanghai Huirui Biotechnology, Shanghai,
China) and Roche Light Cycler 480 (Roche, Basel, Switzerland) were used to detect the expression of SARSCoV-2 ORF1ab gene, $\mathrm{N}$ gene and internal label gene. Specimen with a $\mathrm{Ct}$ value less than 40 was considered to be positive. In this study, three negative control, one positive control and one weakly positive were randomly placed in specimens to detect at the same time.

\section{Statistical analysis}

Descriptive analysis of the variables were expressed as number (\%). The measurement data that meet the normal distribution were expressed as Mean \pm standard deviation $($ Mean $\pm S D)$.

\section{Results}

Detection of SARS-CoV-2 RNA in 12 types of specimens of hospitalized COVID-19 patients

SARS-CoV-2 virus may attack different tissues and organs of human body. In order to understand the distribution of SARS-CoV-2 RNA in different specimens, we collected 1516 available specimens from 1008 severe COVID-19 patients including 463 (30.54\%) cases of nasopharyngeal 
swab, 39(2.57\%) cases of oropharynx swab, $382(25.20 \%)$ cases sputum, 15 (0.99\%) cases of BALF, 262 (17.28\%) cases of stool, 98 (6.46\%) cases of anal swab, 135 (8.91\%) cases of urine, $1(0.07 \%)$ case of peritoneum fluid, 40 (2.64\%)cases of blood, $2(0.13 \%)$ cases of cerebrospinal fluid, 67(4.42\%) cases of corneal secretion and 12 (0.79\%) cases of sweat (Fig. 1).

We performed SARS-CoV-2 RNA detection with the 12 types of specimens from 1008 hospitalized patients with COVID-19 (Table 1). The double positive for both ORF1ab gene and N gene were $64.15 \%(297 / 463)$ in nasopharyngeal swab, $46.67 \%(7 / 15)$ in BALF, $25.64 \%$ $(10 / 39)$ in oropharynx swab, $15.97 \%(61 / 382)$ in sputum, $12.21 \%(32 / 262)$ in stool, $8.89 \%(12 / 135)$ in urine, $8.16 \%$ $(8 / 98)$ in anal swab, $7.50 \%(3 / 40)$ in blood and $1.49 \%$ (1/67)in corneal secretion (Fig. 2). The single positive for either ORF1ab gene or N gene were $20.00 \%(3 / 15)$ in BALF, $12.57 \%(48 / 382)$ in sputum, $7.40 \%(10 / 135)$ in urine, 6.91\% (32/463) in nasopharyngeal swab, 5.13\% $(2 / 39)$ in oropharynx swab, $5.00 \%(2 / 40)$ in blood and $3.05 \%(8 / 262)$ in stool (Fig. 2). No SARS-CoV-2 RNA was detected in PDF and CSF specimens.

\section{Detection of SARS-CoV-2 RNA in 7 types of specimens from discharged patients with COVID-19}

In order to explain the cause about so-called recovered positive, we further analyzed 7 types of specimens of nasopharyngeal swab, oropharyngeal swab, sputum, stool, anal swab, urine and peripheral blood in 20 discharged patients with COVID-19 during quarantine time (14 days). The SARS-CoV-2 RNA positive was found in $8.1 \pm 3.4$ days after discharge, ranging from 4 days to 14 days (Table 2). All of the 6 patients showed positive viral RNA for at least one gene in nasopharyngeal swab, 2 patients had both ORF1ab and $\mathrm{N}$ gene positive, another 3 patients only showed ORF1ab positive and 2 patients showed $\mathrm{N}$ gene positive. The double positive of both ORF1ab and N gene RNA were found in 5 cases at least in one specimen simultaneously, while 2 of which in sputum, 1 of which in nasopharynx swab, 1 of which in anal swab and 1 of which in the 3 specimens (nasopharynx swab, oropharynx swab and sputum) simultaneously. No positive SARS-CoV-2 RNA was detected in the specimens of stool, urine and blood of the 20 discharge patients (Table 2).

During the quarantine time of these 20 patients, the positive rate of SARS-CoV-2 was $30 \%(6 / 20)$ in nasopharyngeal swab, $10 \%(2 / 20)$ in oropharyngeal swab, $15 \%$ $(3 / 20)$ in sputum, and $5 \%(1 / 20)$ in anal swab, respectively. The double positive of both ORF1ab and $\mathrm{N}$ gene RNA were found in $25 \%(5 / 20)$ cases at least in one specimen simultaneously (Fig. 3).

\section{Discussion}

There has been increasing evidences express that SARSCoV-2 RNA could be detected not only in respiratory tract but also in gastrointestinal tract [7, 13]. In this study, 1008 hospitalized severe COVID-19 patients were detected positive SARS-CoV-2 RNA in 12 types of specimens collected from respiratory tract, gastrointestinal tract, urinary system, blood, eyes, the nervous system and sweat. The nasopharyngeal swab specimens showed the highest positive rates $(71.06 \%)$, followed by BALF (66.67\%), oropharyngeal swab (30.77\%), sputum $(28.53 \%)$, blood (12.5\%), stool (12.21\%) and anal swab (11.22\%). We also found the SARS-CoV-2 in urine

Table 1 SARS-CoV-2 RNA in different specimens from COVID-19 patients

\begin{tabular}{|c|c|c|c|c|c|c|c|c|c|}
\hline \multirow[t]{2}{*}{ Types of specimen } & \multirow[t]{2}{*}{$\begin{array}{l}\text { Sample } \\
\text { number }\end{array}$} & \multicolumn{2}{|c|}{$\begin{array}{l}\text { ORF1 } \mathrm{ab} \text { and } \mathrm{N} \text { genes } \\
\text { both positive }\end{array}$} & \multicolumn{2}{|c|}{$\begin{array}{l}\text { Only ORF1ab gene } \\
\text { positive }\end{array}$} & \multicolumn{2}{|c|}{ Only N gene positive } & \multicolumn{2}{|c|}{$\begin{array}{l}\text { ORF1ab and } \mathrm{N} \text { genes } \\
\text { both negative }\end{array}$} \\
\hline & & No. & Rate (\%) & No. & Rate (\%) & No. & Rate (\%) & No. & Rate (\%) \\
\hline Nasopharyngeal swab & 463 & 297 & 64.15 & 28 & 6.05 & 4 & 0.86 & 134 & 28.94 \\
\hline Oropharyngeal swab & 39 & 10 & 25.64 & 0 & 0.00 & 2 & 5.13 & 27 & 69.23 \\
\hline Sputum & 382 & 61 & 15.97 & 37 & 9.69 & 11 & 2.88 & 273 & 71.47 \\
\hline BALF & 15 & 7 & 46.67 & 3 & 20.00 & 0 & 0.00 & 5 & 33.33 \\
\hline Stool & 262 & 32 & 12.21 & 7 & 2.67 & 1 & 0.38 & 230 & 87.79 \\
\hline Anal swab & 98 & 8 & 8.16 & 2 & 2.04 & 1 & 1.02 & 87 & 88.78 \\
\hline Urine & 135 & 12 & 8.89 & 6 & 4.44 & 4 & 2.96 & 113 & 83.70 \\
\hline PDF & 1 & 0 & 0 & 0 & 0 & 0 & 0 & 1 & 100 \\
\hline Blood & 40 & 3 & 7.50 & 1 & 2.50 & 1 & 2.50 & 35 & 87.50 \\
\hline Sweat & 12 & 0 & 0 & 0 & 0 & 0 & 0 & 12 & 100 \\
\hline CSF & 2 & 0 & 0 & 0 & 0 & 0 & 0 & 2 & 100 \\
\hline Corneal secretion & 67 & 1 & 1.49 & 1 & 1.49 & 0 & 0 & 65 & 97.02 \\
\hline
\end{tabular}




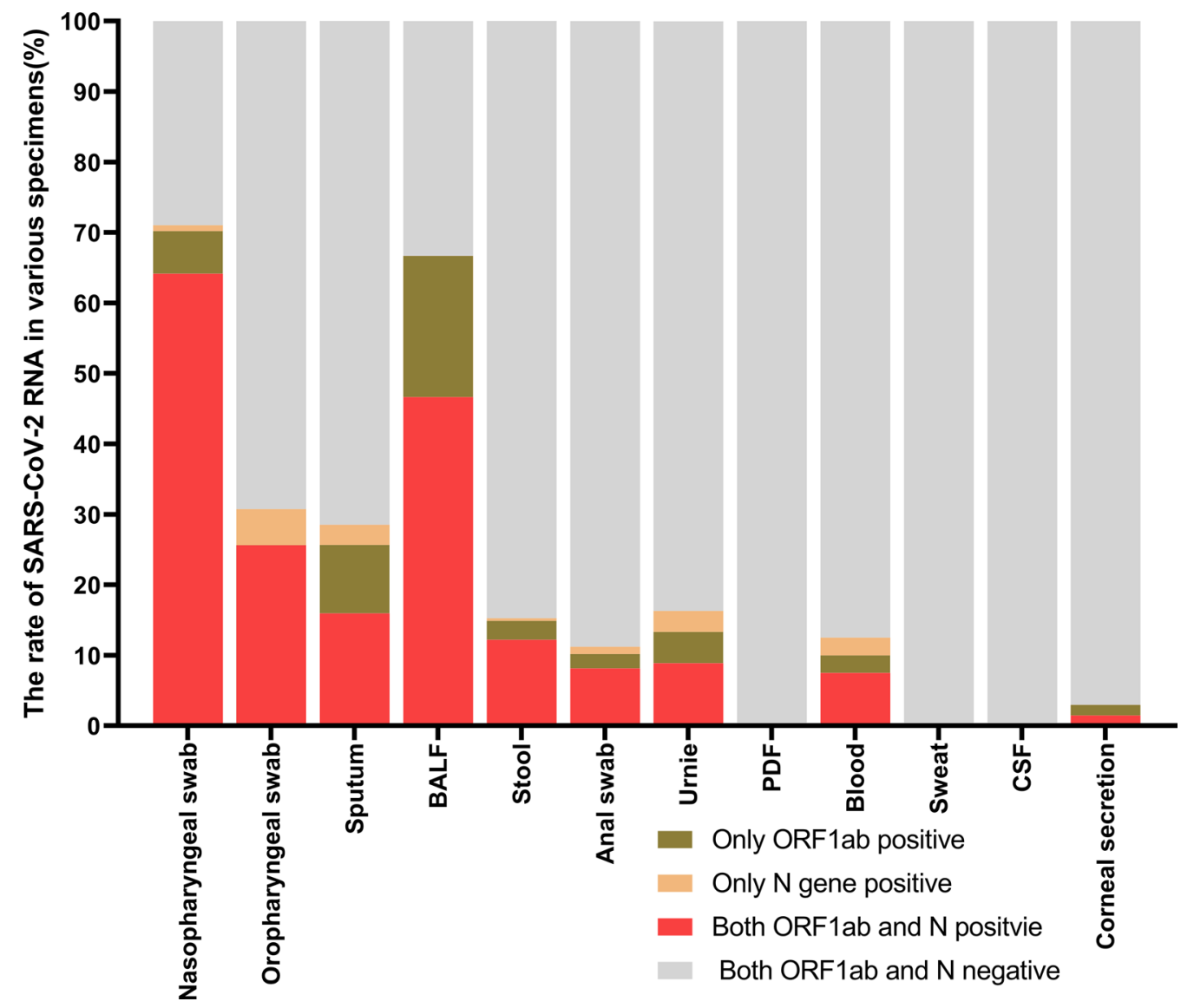

Fig. 2 Positive rate of SARS-CoV-2 RNA detected in different specimens from COVID-19 patients. It was defined as positive when the ORF1ab gene and $\mathrm{N}$ gene were both positive at the same time. It was defined as suspicious when ORF1ab gene or $\mathrm{N}$ gene was positive, which should be resampled to detect again after $24 \mathrm{~h}$

Table 2 SARS-CoV-2 RNA positive in different specimens from the discharged COVID-19 patients in isolation period

\begin{tabular}{|c|c|c|c|c|c|c|c|c|c|}
\hline \multicolumn{2}{|l|}{ Patients } & \multirow[t]{2}{*}{ Gene } & \multirow{2}{*}{$\begin{array}{l}\text { Nasopharyngeal } \\
\text { swab }\end{array}$} & \multirow{2}{*}{$\begin{array}{l}\text { Oropharyngeal } \\
\text { swab }\end{array}$} & \multirow[t]{2}{*}{ Sputum } & \multirow[t]{2}{*}{ Stool } & \multirow[t]{2}{*}{ Anal swab } & \multirow[t]{2}{*}{ Urine } & \multirow[t]{2}{*}{ Blood } \\
\hline Number & Isolated days & & & & & & & & \\
\hline \multirow[t]{2}{*}{ P3 } & 6 & ORF1ab & + & - & - & - & - & - & - \\
\hline & & $N$ & + & - & - & - & - & - & - \\
\hline \multirow[t]{2}{*}{ P6 } & 8 & ORF1ab & + & - & + & - & - & - & - \\
\hline & & $\mathrm{N}$ & - & - & + & - & - & - & - \\
\hline \multirow[t]{2}{*}{ P7 } & 9 & ORF1ab & + & - & + & - & - & - & - \\
\hline & & $\mathrm{N}$ & - & - & + & - & - & - & - \\
\hline \multirow[t]{2}{*}{ P8 } & 4 & ORF1ab & + & - & - & - & - & - & - \\
\hline & & $\mathrm{N}$ & - & + & - & - & - & - & - \\
\hline \multirow[t]{2}{*}{ P12 } & 14 & ORF1ab & - & - & - & - & + & & - \\
\hline & & $\mathrm{N}$ & + & - & - & - & + & - & - \\
\hline \multirow[t]{2}{*}{ P15 } & 4 & ORF1ab & + & + & + & - & - & - & - \\
\hline & & $\mathrm{N}$ & + & + & + & - & - & - & - \\
\hline
\end{tabular}




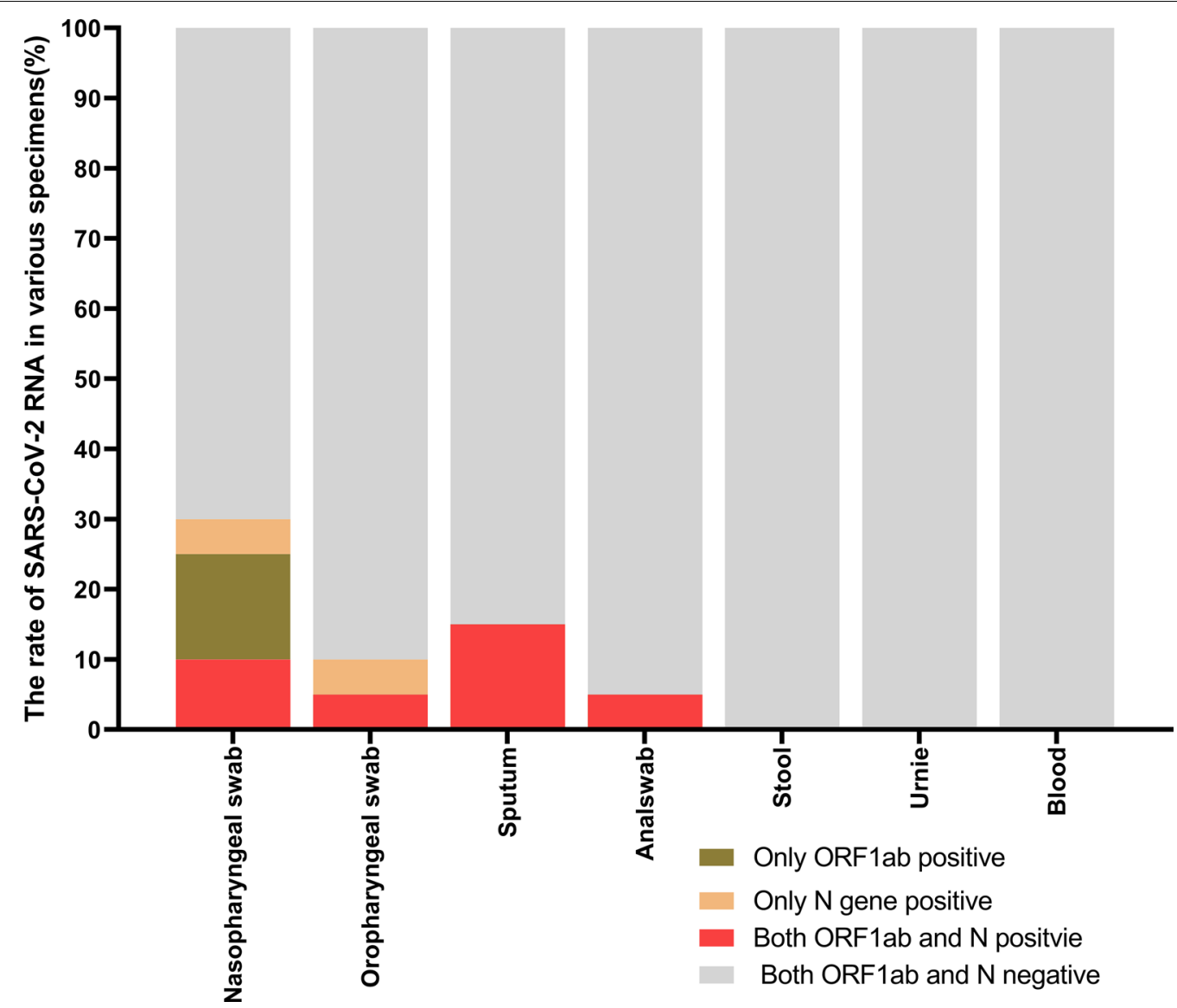

Fig. 3 Positive rate of SARS-COV-2 RNA detected in different specimens from the discharged COVID-19 patients in their isolation period. SARS-CoV-2 RNA was detected in 7 types of specimens before discharging. It could be considered positive when the ORF1ab and N genes were both positive at the same time. It could be considered that SARS-CoV-2 RNA was negative, and the virus was dead when only ORF1ab or N gene was positive

(16.30\%). These features of our results of the viral positive rate among various tissues were very different from a previous study [14]. In this study, the highest SARSCoV-2 RNA positive rate was $71.06 \%$ in nasopharyngeal swab, followed by $66.67 \%$ in BALF, $30.77 \%$ in oropharynx swab, $28.53 \%$ in sputum, $16.30 \%$ in urine, $12.50 \%$ in blood, $12.21 \%$ in stool, $11.22 \%$ in anal swab, and $2.99 \%$ in corneal secretion. These results showed that the specimen should firstly collect nasopharyngeal swabs, followed by oropharyngeal swabs, and collect sputum, stool, anal swabs or blood. The specimen of BALF could be collected for patients with bronchial intubation in inpatient. The specimen of corneal secretion may be collected if there were eye's symptoms for the patients with suspected COVID-19.

The SARS-CoV-2 RNA was found turning back to positive in some patients after discharge for 1 month or longer time. It is urgent to know whether the recovery positive viral RNA is caused by second infection or resulted from uncured patient itself. Therefore, our data bring to the focus of discussion whether it is appropriate to perform viral RNA detection only in two consecutive respiratory specimens (at least 1 day of time interval of sampling) for patients who have reached the standards of quarantine time (14 days) after clinical cured and discharge after treatment [9]. In this study, the SARS-CoV-2 RNA was found in respiratory tract, gastrointestinal tract, urinary system, blood and eyes, which means this virus may appear almost everywhere in human body. So we selected seven types of specimens of nasopharynx swab, oropharynx swab, sputum, stool, anal swab, urine and blood to detect SARS-CoV-2 RNA simultaneously for 20 patients who were clinically cured but still in quarantine time based on the findings of organ infection with SARS-CoV-2 and the convenience of sample collection.

Among 20 discharged patients, 5 of them expressed both ORF1ab gene and N gene RNA positive, in which 2 cases showed positive in sputum, 1 case showed positive 
in nasopharynx swab, 1 case showed positive in anal swab, and 1 case in 3 specimens (nasopharynx swab, oropharynx swab and sputum) showed positive simultaneously. These 5 cases were diagnosed as carriers of SARS-CoV-2. This result showed that the SARS-CoV-2 recovery positive might indicate that patient had not been fully cured when discharged at that time, though it met the criteria of discharge. The results didn't seem to support the possibility of reinfection of the virus. As a result, the current discharge criteria could be improved according to the clinical findings and the sole detection of SARS-CoV-2 RNA in respiratory tract specimen seemed inadequate. It is necessary to collect multiple types of specimens to detect the viral RNA before the discharge of the patients, though they may meet the criteria of clinical cure. Once the patient is detected positive for SARS-CoV-2 RNA in the quarantine time, another 14 days' isolation will be recommended until viral RNA become negative in all of 7 types of the specimens.

The 7 types of specimens that we used in this study may be a good choice, but if the patients have other concurrent diseases, it may also enlarge the scope of additional enrolled specimens to study. Moreover, a larger sample needs to be enrolled to exclude the possibility of peritoneal fluid and CSF containing the SARS-CoV-2 RNA in our cohort. In addition to the 5 cases, another 1 case (P8 at Table 2) was only detected ORF1ab gene RNA from nasopharynx swab and N gene RNA from oropharyngeal swab in the quarantine time, this patient did not meet the criteria of viral carrier. This may suggest that SARS$\mathrm{CoV}-2$ virus is dead and is being cleared by the patients. It is known that false negative of RNA detection in respiratory tract specimens is unavoidable in the severe patients [15]. Therefore, multiple types of specimen should be analyzed simultaneously to exclude the possibility of the discharge patients as the source of infection again.

\section{Conclusions}

SARS-CoV-2 could exist in the various specimens came from different tissues and organs. It is the necessity for detection of SARS-CoV-2 RNA in multiple types of specimens at discharge of the patients with COVID-19. SARS-CoV-2 RNA should be recommended to detect before releasing the isolation period in order to avoid the discharge of patients with false negatives.

\footnotetext{
Abbreviations

COVID-19: Coronavirus disease 2019; SARS-CoV-2: Severe Acute Respiratory Syndrome Coronavirus 2; RT-qPCR: Real-time fluorescence quantitative PCR; PBMCs: Peripheral blood mononuclear cell; CSF: Cerebrospinal fluid; PDF: Peritoneal dialysis fluid.
}

Acknowledgements

Not applicable.

\section{Authors' contributions}

LY, WHM and ZZJ proposed the study idea. TYQ, BAY, and CHB contributed to the literature review. The study was designed by LY, WHM, ZZJ and TYQ. Data collection was done by HJT, LZH, FLN and ZHY. Data analysis was done by ZHY, WZG, CY, WYN and CHB. Molecular analysis was done by HJT, LZH, FLN, $\mathrm{BL}$ and $\mathrm{QB}$. Figures and Tables were created by TYQ, BAY, and CHB. All authors contributed to the writing of the final report. All the authors have accepted responsibility for the entire content of this submitted manuscript and approved submission. All authors read and approved the final manuscript.

\section{Funding}

This work was supported by the Special Science and Technology Cooperation Project of Ningxia Hui Autonomous Region Key R\&D Program (2018BFG02008), Special New Coronary Pneumonia Epidemic Prevention and Control Project of Ningxia Hui Autonomous Region (2020BEG01004).

\section{Availability of data and materials}

All data generated or analyzed during this study are included in this published article.

\section{Ethics approval and consent to participate}

This study was approved by the ethics committees of the Renmin Hospital of Wuhan University (WDRY2020-K078)

\section{Consent for publication}

The written inform consent was obtained from the patients.

\section{Competing interests}

The authors declare that they have no competing interests.

\section{Author details \\ ${ }^{1}$ Department of Clinical Laboratory, Renmin Hospital of Wuhan University, Wuhan 430060, China. ${ }^{2}$ Department of Pulmonary and Critical Care Medicine of Renmin Hospital, Wuhan University, Wuhan 430060, China. ${ }^{3}$ Clinical Labora- tory Center \& Ningxia Key Laboratory of Clinical and Pathogenic Microbi- ology, General Hospital of Ningxia Medical University, Yinchuan 750004, China. ${ }^{4}$ Department of Nephrology, Renmin Hospital of Wuhan University, Wuhan 430060, China.}

Received: 24 June 2020 Accepted: 24 October 2020

Published online: 02 November 2020

\section{References}

1. Huang C, Wang Y, Li X, Ren L, Zhao J, Hu Y, Zhang L, Fan G, Xu J, Gu X, et al. Clinical features of patients infected with 2019 novel coronavirus in Wuhan, China. Lancet. 2020;395:497-506.

2. Zhou P, Yang XL, Wang XG, Hu B, Zhang L, Zhang W, Si HR, Zhu Y, Li B, Huang $C L$, et al. A pneumonia outbreak associated with a new coronavirus of probable bat origin. Nature. 2020;579:270-3.

3. Wu Z, McGoogan JM. Characteristics of and important lessons from the Coronavirus Disease 2019 (COVID-19) outbreak in China: summary of a report of 72314 cases from the Chinese center for disease control and prevention. JAMA. 2020;323:1239-42.

4. Lu S. Timely development of vaccines against SARS-CoV-2. Emerg Microbes Infect. 2020;9:542-4

5. Pang J, Wang MX, Ang IYH, Tan SHX, Lewis RF, Chen JI, Gutierrez RA, Gwee SXW, Chua PEY, Yang Q, et al. Potential rapid diagnostics, vaccine and therapeutics for 2019 novel Coronavirus (2019-nCoV): a systematic review. J Clin Med. 2020;9:623.

6. Coronaviridae Study Group of the International Committee on Taxonomy of $\mathrm{V}$. The species Severe acute respiratory syndrome-related coronavirus: classifying 2019-nCoV and naming it SARS-CoV-2. Nat Microbiol. 2020;5:536-44.

7. Chen W, Lan Y, Yuan X, Deng X, Li Y, Cai X, Li L, He R, Tan Y, Deng X, et al. Detectable 2019-nCoV viral RNA in blood is a strong indicator for the further clinical severity. Emerg Microbes Infect. 2020;9:469-73.

8. Chen N, Zhou M, Dong X, Qu J, Gong F, Han Y, Qiu Y, Wang J, Liu Y, Wei $Y$, et al. Epidemiological and clinical characteristics of 99 cases of 2019 
novel coronavirus pneumonia in Wuhan, China: a descriptive study. Lancet. 2020;395:507-13.

9. Jin YH, Cai L, Cheng ZS, Cheng H, Deng T, Fan YP, Fang C, Huang D, Huang LQ, Huang Q, et al. A rapid advice guideline for the diagnosis and treatment of 2019 novel coronavirus (2019-nCoV) infected pneumonia (standard version). Mil Med Res. 2020;7:4.

10. Cao H, Ruan L, Liu J, Liao W. The clinical characteristic of eight patients of COVID-19 with positive RT-PCR test after discharge. J Med Virol. 2020 https://doi.org/10.1002/jmv.26017.

11. Lan $L$, Xu D, Ye G, Xia C, Wang S, Li Y, Xu H. Positive RT-PCR test results in patients recovered from COVID-19. JAMA. 2020;323:1502-3.

12. Diagnosis and treatment guidelines of coronavirus disease 2019 in China - 7th Edition (English Translation on ELotus.com). China's National Health Commission.https://exploreim.ucla.edu/covid19/chinas-nationalhealth-commission-guidelines-for-covid-19-treatment-2-2/).
13. Peng L, Liu J, Xu W, Luo Q, Chen D, Lei Z, Huang Z, Li X, Deng K, Lin B, Gao Z. SARS-CoV-2 can be detected in urine, blood, anal swabs, and oropharyngeal swabs specimens. J Med Virol. 2020. https://doi.org/10.1002/ jmv.25936.

14. Wang W, Xu Y, Gao R, Lu R, Han K, Wu G, Tan W. Detection of SARS-CoV-2 in Different Types of Clinical Specimens. JAMA. 2020;323:1843-4.

15. Xiao AT, Tong YX, Zhang S. False-negative of RT-PCR and prolonged nucleic acid conversion in COVID-19: rather than recurrence. J Med Virol. 2020. https://doi.org/10.1002/jmv.25855.

\section{Publisher's Note}

Springer Nature remains neutral with regard to jurisdictional claims in published maps and institutional affiliations.
Ready to submit your research? Choose BMC and benefit from:

- fast, convenient online submission

- thorough peer review by experienced researchers in your field

- rapid publication on acceptance

- support for research data, including large and complex data types

- gold Open Access which fosters wider collaboration and increased citations

- maximum visibility for your research: over $100 \mathrm{M}$ website views per year

At BMC, research is always in progress.

Learn more biomedcentral.com/submissions 